\title{
A Study on the Translation of Discourse Marker "Well" in Friends under the Perspective of Adaption Theory
}

\author{
Anan Hu \\ East China University of Science and Technology, Shanghai, China \\ Email:136030330@qq.com
}

How to cite this paper: Hu, A.A. (2020) A Study on the Translation of Discourse Marker "Well" in Friends under the Perspective of Adaption Theory. Open Access Library Journal, 7: e6827. https://doi.org/10.4236/oalib.1106827

Received: September 16, 2020

Accepted: October 19, 2020

Published: October 22, 2020

Copyright $\odot 2020$ by author(s) and Open Access Library Inc.

This work is licensed under the Creative Commons Attribution International License (CC BY 4.0).

http://creativecommons.org/licenses/by/4.0/

\section{(c) (i) Open Access}

\begin{abstract}
Discourse Markers wildly exist in our daily communication. "Well", as a typical discourse marker, plays a significant role in conversation. In the subtitle translation of film and television series, the translation of discourse markers has significant values, especially in shaping the character's personalities and describing their psychological activities. Based on the above analysis, this paper takes the American sitcom Friends as the corpus source and Verschueren (1999)'s linguistic adaptation theory as the theoretical framework. This paper focuses on communicative context, including communicators' mental, social and physical worlds and analyzes the free translation of discourse marker "well" in Friends under the perspective of adaption theory. Meanwhile, compared original subtitle with the author's revised versions under the guidance of adaption theory.
\end{abstract}

\section{Subject Areas}

Linguistics

\section{Keywords}

Adaption Theory, Friends, Translation, Discourse Marker, "Well"

\section{Introduction}

\subsection{Definition and Characteristics of Discourse Markers}

Schiffrin (1987) [1] is the earliest scholar to conduct systematic research on discourse markers. She believes that "the sequential dependency of the discourse unit as a segmentation is called discourse markers". Fraser (1999) [2] first studied discourse markers from a pragmatic perspective. He pointed out: "Dis- 
course markers are derived from conjunctions, adverbs, and prepositional phrases, and are not independent grammatical units; they have procedural meaning but no conceptual meaning"; Blakemore [3] applies relevance theory to the study of Discourse Marker and he believes that the criteria for dividing Discourse Marker is not certain. This paper selects the typical high-frequency Discourse Marker "well” in oral English as the research object.

\subsection{Studies of the Discourse Marker "Well"}

Lakoff (1973) [4] was the first scholar to study Discourse Marker "well" abroad. In his opinion, "the use of 'well' indicates that the speaker believes that the response he is about to receive is incomplete, or that the expression of another person is inadequate or inappropriate. The speaker experience insufficiency in the entire utterance or behavior". Schiffrin considered "well" to be a response marker, which shows that the coherent choice provided by the preceding utterances for the subsequent responses has not been followed exactly.

Compared with foreign countries, the study of domestic discourse markers is still in its infancy, but it has also achieved certain accomplishments. For example, On the Representation of Pragmatic Functions of Discourse Marker "WELL" in English-Chinese Translation (Wu Yong, Zheng Shutang, 2007) [5], applying the pragmatic function of discourse marker "WELL" to the field of translation; English Majors' Acquisition of Discourse Marker "WELL", An Empirical Study of Pragmatic Functions (Li Min, Chen Xinren, 2007) [6], using examples to explore problems of English major students in the study of "well"; Adaptation Research on Discourse Marker "well” (Gu Jincheng, 2010) [7], applying adaptation theory to the analysis of discourse markers.

\subsection{Verschueren's Adaptation Theory}

In 1987, the Belgian pragmatist Verschueren published A Comprehensive Bibliography of Pragmatics [8], and for the first time proposed the adaptation theory. A Handbook of Pragmatics was published in 1995 [9], which systematically developed the theory, putting forward four core concepts: Selectivity, Variability, Negotiation, and Adaptability. Verschueren believes that the use of language is a process of language selection. For variability, the process of making coices is not static but dynamic. Some out-dated expressions may be used less frequently or completely vanished.

In the book of Understanding Pragmatics [10], Verschueren put forward that context is generally divided into communicative context and linguistic context; linguistic context means the context in which the speech event takes place; while communicative context can be further divided into language users, physical, social and mental world. Language users refer to speakers and listeners; social world includes speaking situations, interpersonal relationships of speakers, etc.; psychological world refers to the psychological activities and emotions of listeners and speakers, including beliefs, desires, motivations. Physical world involves 
factors such as time and space. In terms of time, it includes the time of the event, the time of speaking, and the time of reference. Space includes absolute spatial relationship, space between speakers and reference space. This paper focuses on how the translation strategies of the Discourse Marker "well" adopt to the social, psychological and physical worlds.

\section{Research Corpus and Research Methods}

Friends, an American TV sitcom from September 22, 1994 to May 6, 2004 in Broadcast on the National Broadcasting Corporation (NBC), is directed by David Klein and Marta Kuffman. It has a total of 10 seasons and 236 episodes. The dialogue involves various scenes of family, workplace, park, hotel, school, etc. It vividly depicts many aspects of American society, including social values, gender difference, family, occupations, religion, education, etc., and the language is natural and true. Therefore, Friends is a high-quality material for detailed analysis of the translation of the Discourse Marker "well".

The corpus of this paper comes from the Internet (http://www.zimuku.la), as shown in Table 1 and Table 2. It is calculated that "well" appears in Friends for a total of 4244 times and 354 times in the $10^{\text {th }}$ Season alone. Among the 354 "well" appear in the $10^{\text {th }}$ season, 21 of them have practical meanings, while the other 333 occur as discourse markers. This study focuses on the analysis of the 333 "well" appear in the $10^{\text {th }}$ season, and conduct a comparative study between the free translation of the original subtitles and the revised versions by the author under the guidance of adaption theory.

\section{Free Translation of Discourse Marker "Well" in Friends}

\subsection{Translation Strategies of Discourse Marker "Well” in Friends}

Based on Table 3, we can find that more than half of well appeared in the text are omitted in tranlation, and free translation is the mostly adopted approach. However, omission may lead to losing the flavor of the dialogues, while it's difficult to apply certain standards towards free translation. Therefore, in this chapter, the author would revise a number of translations of "well" in the original Chinese subtitle under the guidance of adaption theory by analyzing the social, mental and physical worlds of the speakers.

Table 1. Most frequently-used discourse marker in total seasons of "Friends".

\begin{tabular}{cccccc}
\hline Discourse Markers & well & you know & I mean & okay & actually \\
\hline Frequency & 4334 & 1762 & 1635 & 4984 & 640 \\
\hline
\end{tabular}

Table 2. Most frequently-used discourse marker in the $10^{\text {th }}$ season of "Friends".

\begin{tabular}{cccccc}
\hline Discourse Markers & well & you know & I mean & okay & actually \\
\hline Frequency & 354 & 264 & 118 & 272 & 38 \\
\hline
\end{tabular}


Table 3. The translation strategies of discourse marker "well" in Friends season $10^{\text {th }}$.

\begin{tabular}{ccc}
\hline Translation strategies & Frequency & Percentage \\
\hline Omission & 194 & $58 \%$ \\
Free translation & 110 & $33 \%$ \\
The rests & 29 & $9 \%$ \\
\hline
\end{tabular}

\subsection{Free Translation of Discourse Marker "Well" from the Perspective of Contextual Correlates}

\subsubsection{Adaption to the Social World}

Example 1:

Benjamin: Break up with Charlie!

Ross. What?

Benjamin: What?

Ross. Did you just say "Break up with Charlie"?

Benjamin: well, yes, and now. Yes I did say it, and no, I didn't not say it. (Episode 6, The One With Ross's Grant)

Translation:

本杰明: 和 Charlie 分手吧!

罗斯: 什么?

本杰明: 什么?

罗斯: 你刚才说“和 Charlie 分手”吗?

本杰明: 好吧, 可以说是, 也可以说不是. 是, 我是这样说了; 不是, 是我没 有否认.

(Revise: 其实呢，可以说是，也可以说不是. 是，我说了; 不是，我没有否认 我说了).

The ex-boyfriend of Ross's girlfriend blurts out that he wanted Rose to break up with Charlie. In this case, Rose was naturally shocked and even felt being offended. Benjamin was also aware of his rudeness and wanted to say something to make up for it. So he added "well" in before explianing. On the one hand, he was not sure about how to organize his words, On the other hand, "well" played a role in alleviating the embarrassing situation. Therefore, "well" in this case can be freely translated as: “是这样的”; ”其实呢”; ”我是说”; ”你听我说”. Those expressions in Chinese not only help to spare others' feelins, but relieve the tension between the two sides.

Example 2:

Man: Hey Rach, I just heard. I m so sorry.

Rachel: Oh, thank you... (looks at his face trying to remember his name).

Man: You still don't know my name, do you?

Rachel: (Is embarrassed for a moment, but it quickly passes) well, now I don't have to.

(The man leaves instantly) (Episode 14, The One With Princess Consuela)

Translation: 
男人: Oh, 这里, Rach. 我刚听见. 我很抱歉.

瑞秋: Oh 谢谢.

男人: 还是不知道我的名字, 是吗?

瑞秋: 嗯, 现在我不用知道了.

(Revise: 对是对, 但是吧.......我现在也不必知道了).

In this scene, a colleague of hers wanted to make a greet with, but Rachel couldn't remember his name and couldn't find anything to say but "well", for she needed time to think about how to respond to avoid hurting the man's feeling. At last, Rachel humorously said: “well”, now I don't have to. The implication was that I had already been dismissed so we had no chance to meet again. Rachel successfully shifted the focus of the conversation by her language. In this case, “well” can be translated “对是对, 但是吧......” to distract the listener's attention.

\subsubsection{Adaption to the Mental World}

Example 3:

Ross. Uhm, I hadn't known you... I had no idea you were so excited about Paris. Uhm, I mean, you said you were scared.

Rachel: well, yeah, but I mean, it was good scared though, you know? Like when I-moved-to-New-York scared. Or uhm, when I-found-out-I-was-gonna-have-Emma scared... But this is... fine. This is gonna be good. (they both stare around) (Episode 15, The One Where Estelle Dies)

Translation:

罗斯: 我不知道你为巴黎如此着迷. 你说过你感到害怕.

瑞秋: 对, 我想这是良性的害怕. 我搬来纽约时, 我感到害怕. 当我发现怀 上 Emma 时, 我感到害怕. 这很不错啦, 能行的.

(Revise: 话虽如此, 但是我想这是有益的害怕. 就好像刚搬到纽约时的害 怕; 怀上 Emma 时的害怕......这是对我有益的害怕, 不会有事儿的).

Under the framework of adaptation theory, both utterers' and interpreters' mental states have significant influence on linguistic choice-making; utterers' choice-making affects utterance production, while interpreters' choice-making influences utterance interpretation.

At this moment, Rachel was going to work in Paris, but Ross wanted her to stay. However, he hesitated when he learned that Rachel is full of expectations and enthusiasm for the trip to Paris. On the other side, Rachel was struggling, not knowing how to say goodbye to Ross. We can see that the speaker uses more than one discourse markers in this dialogue, such as "Uhm", "I mean", "you know", "well". The authenticity of the dialogue was reflected through struggling and hesitating of the speaker. At the same time, the audience was able to experience the inner thoughts of the speaker. “well” can be translated here as “话是 这么说”, “虽然如此”, “确实有一点儿” to reproduce the similar emotion.

Example 4:

Joey. 1 m just mad at my agent.

Phoebe: Estelle? Why? 
Joey. There's a part in a TV movie that I would be perfect for and I didn't even be put up for it! She'd better have a good reason.

Phoebe: I m guessing she does.

Joey: well (taking his cell phone out of a pocket) I $m$ wanna hear it, because she keeps doing this.

Phoebe: well, no, no, wait, wait, wait. All right, I gotta go. Just listen. Promise me, that you will wait a minute before you call her. (Episode 15, The One Where Estelle Dies)

Translation:

乔伊: 我在生我经理人的气.

菲比: Estelle? 为什么?

乔伊: 有一部电视电影, 其中的角色很合适我演. 她没有推荐我去. 她必须 告诉我原因。

菲比: 我想她是原因的.

乔伊: 我想听听, 她老是这样.

(Revise: 既然如此, 我倒要听听她要怎么解释).

菲比: 噢, 等等. 我要先走了. 答应我, 等一会再打给她.

In this example, Phoebe knows Joey's agent Estelle passed away, while Joey is kept in the dark. Phoebe knows that if Joey knows the grievous news, he would be rather sad, so Joey uses "well" to express his negative feelings which may have bad influence on the relationship between Joey and Estelle if Estelle is alive, if Joey knows the death of Estelle, no wonder how upset he will be; and then Phoebe adopts "well" as a delay and adapts to Joey's mental world. In Chinese, “等等” “啊” “喂喂喂” “先冷静一会” can also be served to the same purpose.

\subsubsection{Adaption to the Physical World}

Example 5:

Phoebe: What's Emma doing today?

Rachel: well, let's see... uh... I know that she has a meeting with her lawyer and then she has to make a very big poop. Why? (Episode 8, The One with The Late Thanksgiving)

Translation:

菲比: 烸, 瑞秋，爱玛今天有事么?

瑞秋: 嗯......我只知道她今天要和律师见面, 然后没想到她拉裤子了. 怎么 了?

(Revise: 嗯......她啊, 我想想, 我只知道她今天要和律师见面, 然后没想到 她拉裤子了. 怎么了)?

The physical world is divided into time and space. In this scene, Rachel is busy with looking after her baby, so talking to Phoebe is not her priority. She was half a beat slower when she answered the question, so she added the a "well" to spare time for organizing her words. In translation, you can use: “呃”; “嗯”; “她啊”; “我想想”; “我看看” to buffer the speed of the conversation and organize the language at the same time.

Example 6: 
Monica: well, I was dancing around, and singing No Woman, No Cry and I got stuck.

Chandler. You can't move at al?

Monica: Oh, well, I can move... (she moves back and forth the shower curtain rail, opening and closing the shower curtain with her hair as she goes)

Translation:

莫妮卡: 好吧, 我唱着 “No Woman, No Cry”跳舞.......然后就挂住了.

(Revise: 快帮我一把, 我唱着 “No Woman, No Cry” 跳舞......然后头发卡 在浴帘上了).

钱德勒: 一点都动不了?

莫妮卡: 噢, 不, 我可以动...... (莫妮卡前后动了动头, 头发上缠绕着的浴 帘也一起跟着动).

In this scene, the characters' body language should be given priority. Monica's hair got stuck and in a desperate condition. So her expression should be urgent, calling for help. And dialogue is not the focus, it should be concise and efficient, hitting the point. The translation should adopt to their physical world, that is the speaker's body condition. Given that, instead of “好吧” the proper translation of “well” could be “快帮我一把”, which indicates the emergency that Monica was going through, meanwhile, the audience can have stronger empathy for it.

\section{Conclusions}

Discourse markers have been extensively discussed by scholars at home and abroad. In the field of translation, especially the subtitle translation of film and television works, DMs lacks standard to reference. The translation of DMs directly affects the audience's appreciation of the characters' language and personalities. Therefore, when translating "well", translators are required to look deeper into the speakers' social, psychological and physical worlds. According to the author's statistics, it can be seen that in the subtitle translation of Friends, free translation is widely applied to convey the hidden meaning of dialogues. And omission, though being the most frequently used method in the translation of "well", is not the optimal choice in most cases, and more flexible and expressive versions should be adopted. Through revising the translation of "well" and comparing the revised versions with the original after thoroughly analyzing the speaker's psychological activities, social demands and physical states, the author managed to illustrate the feasibility of translating "well" under the guidance of adaptation theory.

However, this paper has its limitations. Firstly, the author only collects data from tenth season so the research corpus is insufficient; secondly, more examples should be presented to support the conclusion; thirdly, only free translation is discussed in this paper while other translation strategies are not involved.

\section{Conflicts of Interest}

The author declares no conflicts of interest regarding the publication of this paper. 


\section{References}

[1] Schiffrin, D. (1987) Disccourse Markers. Cambridge University Press, Cambridge.

[2] Fraser, B. (1996) Pragmatic Markers. Pragmatics, 6, 167-190. https://doi.org/10.1075/prag.6.2.03fra

[3] Blakemore, D. (2002) Relevence and Linguistic Meaning: The Semantics and Pragmatics of Discourse Markers. Cambridge University Press, Cambridge. https://doi.org/10.1017/CBO9780511486456

[4] Lakoff, R. (1973) Questionable Answers and Answerable Questions. In: Kachru, B.B., et al., Eds., Issues in Linguistics. University of Illinois Press, Urbana, 453-467.

[5] 吴勇, 郑树棠. 论话语标记语 WELL 语用功能在英译汉中的再现[J]. 外语与外语 教学, 2007(7): 47-52.

[6] 李民, 陈新仁. 英语专业学生习得话语标记语 WELL 语用功能之实证研究[J]. 外 语教学与研究, 2007(1): 21-26+80.

[7] 顾金成. 话语标记语“well”的顺应性研究[J]. 外国语文, 2010, 26(4): 65-69.

[8] Jan, N. and Jef, V. (1987) A Comprehensive Bibliography of Pragmatics.

[9] Jef, V., Jan-Ola, Ö. and Jan, B. (1995) Handbook of Pragmatics: Manual.

[10] Verschueren, J. (1999) Understanding Pragmatics. Foreign Language Teaching and Research Press, Beijing. 